\title{
Nazi Chic? fashioning women in the Third Reich
}

Irene Guenther; Berg, 0xford and New York, 2004, ISBN 1-85973-400-6, £55.00 (hbk), ISBN 18-59-73-717 X, £17.00 (pbk)

The title of Irene Guenther's book does not adequately represent the scope of her research or her wide-ranging argument. The book sets out to show how fashion in all its dimensions was critical to the pursuit of economic prosperity in the German nation that re-emerged after the Great War. Guenther has gathered an impressive array of sources that document the development of the fashion industry as a means of politically differentiating German innovation and modernity, initially from all things French but ultimately from the defeated and demoralized Weimar. Her argument is that fashion carried the meanings of a new nationalism, and her account of the intersections of culture and politics embraces the organization and regulation of the clothing industry, education and training for designers, promotion and publicity through trade fairs and fashion journalism, and the marketing and consumption of style.

Although Guenther discusses both 'costume' (the dirndl) and uniforms, her argument is not about ethnicity or militarism; instead its focus is on the centrality of modern versions of gender and femininity to the construction of a 'new' Germany. Her claims are well demonstrated, and the variety of sources is impressive. Indeed, the evidence she accumulates at times overwhelms her narrative. However, this is a fascinating perspective on the workings of cultural construction. In particular, the systematic substitution of German words to undermine the hold of French on the lexicon of fashion shows how intimately culture and politics are connected. 'Buy German' campaigns instituted a new vocabulary: 'couture' became 'Hauptmode'; 'Confection', (ready-to-wear) became 'Konfektion'; and 'chic' became 'Schick'.

Jews were at the centre of the clothing trade: they were the tailors, the machinists and the merchants. The book begins with a story from the camps. In a workroom close by the crematoria at Auschwitz, seamstresses fashioned stylish wardrobes for the wives of the SS and for female officers. Each week, each worker produced two custom made garments, to be collected on Saturday. The materials came from 'Canada', the warehouses where the effects of the Jews who had been sent to the gas were stored. Those in the workroom were spared that fate, and earned a little more bread. Guenther quotes a female guard who praises the work: 'When the war will be over [sic], I am going to open a large dressmaking studio with you in Berlin. I never knew that Jewesses could work, let alone, so beautifully' (p. 5). 
Ordinary women suffered from wartime shortages: all kinds of materials, including fishing net, plexiglass and paper were pressed into use to make, repair and extend the life of threadbare garments. Parachute silk was prized for underwear, but harsh penalties applied to those who appropriated it for their own use. Those ordinary women, however, were not the targets of the publicity that promoted German 'chic' in the period between the wars. The designs of the Modeamt (fashion institute) headed by Professor Margarethe Klimt, were aimed at rich and stylish women. The text reproduces illustrations from the trade papers and the wider fashion press and advertising. Guenther's discussion shows how Nazi 'anti-vamp' and 'anti-cosmetics' campaigns were conducted and contested in the pages of the magazines. American companies like Elizabeth Arden (a favourite of Eva Braun), and Hollywood stars like Katherine Hepburn, Greta Garbo and Marlene Dietrich, featured prominently. Despite her repudiation of the National Socialist regime, Dietrich's 'natural' beauty and her adoption of the 'dirndl' look contributed to the popularity of the peasant style and unwittingly endorsed Goebbels' propaganda.

One of Guenther's objectives is to make a case for the serious consideration of fashion in cultural and social history: historians, she repeatedly states, dismiss fashion as 'trivial'. Within the disciplines of art history and cultural studies, fashion has a growing importance. Berg, the publishers of this book, have an expanding list of fashion titles. However, it is arguable that social historians have treated fashion as a limited and limiting subject. This may be because fashion is not just aligned with femininity, but with consumption. Feminist scholarship has had a significant impact on social history, redefining 'work' and repositioning women workers. Analyses of work in the textile and clothing industries have shown how technological change and unionisation have impacted on the gendered organisation of the trade. 'Fashion', however, signifies something other than this: something both excessive and ephemeral. 'Consumption' and 'taste' have emerged as key concepts in the new cultural sociology, and writers like Rita Felski have continued feminist interest in the complex intersections of culture and politics. Guenther's distinctive contribution is in documenting, in comprehensive and painstaking detail, the place of fashion in the political program of a modernising and industrial state and its function in advancing the Nazi ambition of a pure Aryan nation.

\section{Kay Ferres}

